\title{
The Implementation of Government Administration in Gampong Blok Sawah
}

\author{
Ismail \\ Universitas Iskandar Muda, Indonesia \\ ismail.unida@gmail.com
}

\section{Abstract}

The purpose of this study was to determine how the implementation of Gampong government administration and the obstacles experienced in the management of Gampong government administration at Keuchik Gampong Office, Block Sawah, Pidie Regency. The method used is a qualitative approach, data collection through observation, documentation, and interviews. In the data validity checking technique used triangulation with the use of sources. The results of the study found that the apparatus of the management of Gampong government administration was not fully capable of providing services to the community as desired by the community. However, if the obstacles faced in carrying out the management of Gampong government administration are human resource factors and their good management in the process of carrying out implementing administration mechanisms for the community so that it is easier to complete administrative arrangements. From the results of the above study it can be concluded that the implementation of Gampong government administration at Keuchik Gampong office Blok Sawah, Pidie Regency provided by officers in general is in accordance with established procedures, however the community still wants an improvement in the quality of administrative management, so that it is faster and not convoluted.
Keywords

implementation; administration; Gampong government

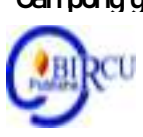

\section{Introduction}

The granting of authority to the gampong government is the first step in order to speed up service at Gampong level. This happens because of the government's relationship with the community in the context of carrying out sustainable development. Gampong is the smallest community structure under the mukim. The implementation of gampong government is a fundamental reflection of the prevailing adat in Aceh. Gampong government consists of Keuchik and Gampong Consultative Society called tuha peut, or another name. In carrying out their duties Keuchik is assisted by a Gampong apparatus consisting of a Gampong secretary and other Gampong apparatus. In articles 2 and 3 of Qanun Number 5 of 2003 concerning Gampong Government, that gampong is the lowest government organization under the mukim in the organizational structure of government in Aceh Province.

Administration of Gampong Government must be carried out properly so that it can support the implementation of activities in the governance of decision making. Management and improvement and development of Gampong administration are expected to support the smooth implementation of administrative tasks. Gampong office is a place where employees work to serve all the needs that are needed by the community such as a 
letter to make a KTP (Identity Card), a request for a birth certificate, family card documents $(\mathrm{KK})$. and so forth. In the sense of proportion to the interests, namely bureaucracy oriented to service to the community.

Implementation is carried out by employees of Keuchik Gampong Blok Sawah office in various service sectors especially those concerning the fulfillment of civil rights and basic needs of the community such as, moving certificate, certificate of disability, certificate of domicile, KK service, birth certificate, etc. not as expected. Concerning convoluted working procedures and mechanisms in the administration, not transparent, less accommodating, less consistent and less informative limited facilities and infrastructure so that it does not guarantee certainty (time and cost).

In connection with the implementation of Gampong Government administration, cooperation between various parties is needed for the apparatus, employee work discipline at Keuchik Gampong Blok Sawah Office is felt to be lacking. Based on preliminary observations and the reality, it turns out that there are facts that are emperis in the field is that the process of administering the administrative government has not been able to run properly. In terms of human resources and facilities and infrastructure. Not enough. In the administration of government administration, management is needed in every process of implementation activities so that it can run as planned. To be able to provide optimal results in the implementation of administrative tasks of gampong, it is necessary to have sufficient ability and willingness both in terms of the ability and quality of the implementation apparatus itself and from supporting facilities, including also the conditions of work carried out so that it will be directed to the existence of a unified action and in the end provide good service for the progress of the village.

Therefore we need the ability, willingness and means that can support the smooth implementation of Gampong administration. In the administration of gampong governance, of course, it is inseparable from the relationship between the government and the governed, and a process of proper governance shows a great responsibility, in order to realize a good governance.

\section{Review of Literature}

\subsection{Public Service Theory}

Service is the main task that is essential from the figure of the apparatus, as servants of the state and servants of society. According to Wahyudi (2014) that:

Weaknesses in public services are not only caused by the lack of good service at the lower levels, it turns out there are still many factors that affect the poor working procedures in the bureaucracy. The attitude of the views of government bureaucratic organizations, which are always oriented towards activities, and formal accountability. The emphasis on product or service quality is very lacking, so that gradually the work in the organization becomes less challenging and less demanding.

The government as a service provider for the public is required to provide quality services. Especially in the era of regional autonomy, the quality of government apparatus services will be increasingly challenged to be optimal and able to answer the increasingly high demands of the community, both in terms of quality and in terms of service quantity. In developing countries, we can see the quality of public services is a problem that often arises, because in developing countries the demand for services generally exceeds the ability of the government to fulfill them so that the services provided by the government to the public are less fulfilled both in terms of quality and quantity. 


\subsection{Administrative Theory}

Gampong Administration is very important for the activities of Gampong Government. Gampong government will run smoothly when supported by a proper, neat and orderly administration / administration system. A correct, neat, and orderly administration system will provide easy and systematic data and information that is very useful for decision making, plan making, evaluation, and communication and information both inside and outside the organization. If it is simplified, the main characteristics to be called as administration, according to Silalahi (2011) are:

1) Cooperation is carried out by a group of people.

2) Cooperation is carried out based on a structured division of labor.

3) Cooperation is intended to achieve goals.

4) To achieve the goal of utilizing resources.

Based on the definitions and concepts above, basically Administration is an activity on the management of all components of the organization to achieve efficiency in achieving organizational goals, so it can be said that Administrative activities are the sum of operational and management work. Administration includes all activities that are planned and carried out regularly to achieve the educational goals outlined. Good administration is an administration that has an administration that meets at least five requirements, namely complete, modern, precise, convincing, and stored in such a way that it is easy to trace and use as a decision support tool if needed.

According to Nurcholis (2011: 135) said that: Gampong administration is the whole process of recording data and information regarding the administration of gampong government". Based on the foregoing understanding and when associated with activities at Gampong level, speaking of Gampong administration means that what is meant by administration is a series of activities carried out by Gampong administration to achieve the objectives of the government, such as in both promoting participation in development and the realization of Pancasila Democracy real in order to improve people's lives.

\subsection{Human Resources Theory}

Human resources need to be paid attention to, maintained, and developed. Quality human resources will produce the desired results. Good quality is not only clever but also fulfills the qualification requirements required from work, so that it can be completed according to plan. Human resource development is an effective way to overcome some of the challenges faced by most large organizations. Human resource development at this time, can be seen as the growth of capabilities that occur far beyond what is required in a job.

The purpose of developing Human Resources (HR) is to improve the level of ability possessed by Gampong apparatus, so that it implies on the effectiveness of employee performance in achieving the results set. While the nature of development itself is the development of knowledge, skills development, and overall attitude change in life related to work quality. According to Kaswan (2012) human resource management is "Part of management which includes, among others, planning, organizing, directing, and others. Human resource management handles human resources that is people who are ready, willing and able to contribute to the goals of human resource management ".

\subsection{Organizational Theory}

Organization is an indispensable element in human life especially in modern life. The organization helps us carry out things or activities that cannot be carried out properly as individuals. Organizations have very varied meanings, depending on what angle people 
look at them. Organizations can be seen as a container, process, behavior, and as a means to an end. Mooney in Manullang (2014) said that organization is "the form of every human union to achieve a common goal". According to Barnard in Manullang (2014) provides an understanding of the organization as "A system of cooperative activities carried out by two or more people". Siagian in Daryanto (2015) organization as "Form of union between two or more people who work together for a common goal and be formally bound and there is a relationship between a person called the leader and a group of people called subordinates".

In general, organizations are divided into two forms, first profit-oriented organizations such as companies that provide products or services (both large and small companies) then non-profit or non-profit organizations such as foundations, museums, government-owned hospitals, schools, social associations and others. Whatever form the organization requires efforts to manage the activities and people and other elements in the organization in order to achieve goals better. Therefore Max Weber in Thoha (2014) mentions organizations with:

Demonstrating his opinion on bureaucracy, differentiating a working group, with social organizations, a working group is a social relations system that is linked and limited by rules. These rules as far as possible can force someone to do work as a steady function, either done by the leadership or by other administrative employees.

According to Thoha (2014) organizational theory is "The theory that discusses human behavior ranging from humans in groups to humans in government". Whereas administrative theory is a theory that bases on human behavior in work groups as a basis for state administration theory. Based on the organizational understanding stated above, providing information that the organization consists of two major parts, as explained by Robbinson in Thoha (2014) as follows:

a. Organization as a container or place, subsystem. This understanding is not like we see homes, rooms, gardens, offices, etc., only in the human mind;

b. Organization as a process that describes activities that will, are, or have been carried out by humans who join a social organization.

The development of the organization was further marked by a structural emphasis as Thompson argued in Thoha (2014) outlining that "the organization put emphasis on the level of rationality in the collaborative effort". Whereas Barnerd in Thoha (2014) states "Determining a coordinated system of cooperation that is consciously coordinated and if we look deeper we will find the same perspective from each formula". Thus the organization is a human tool to organize themselves, the division of work and income so that humans do not ignore the existence of the organization, so that through the organization can carry out work effectively and efficiently, so that Caplow in Thoha (2014) states as follows:

a. The organization has an identity;

b. The organization has continuity;

c. The organization has a work schedule (calendarity);

d. The organization has authority.

\subsection{Gampong Concept}

According to Law Number 6 of 2014 concerning villages article 23 states that the Village government is organized by Village Government.

Implementation of Village Governance based on the principle:

a. legal certainty;

b. orderly administration of government;

c. orderly public interest; 
d. openness;

e. proportionality;

f. professionality;

g. accountability;

h. effectiveness and efficiency;

i. local culture;

j. diversity; and

k. participatory.

According to Law Number 6 of 2014 concerning Villages Article 18 states that Village Authority covers the authority in the field of administering Village Government, the implementation of Village Development, the fostering of Village communities, and the empowerment of Village communities based on community initiatives, rights of origin, and Village customs. In Articles 2 and 3 of Qanun No. 5 of 2003 concerning gampong government, states that gampong is the lowest government organization under the mukim in the organizational structure of the government of Nanggroe Aceh Darussalam Province. Gampong has the task of organizing government, carrying out development, fostering the community and improving the implementation of Islamic Sharia.

\section{Reseach Methods}

This research was conducted at Keuchik Gampong Block Sawah office Pidie Regency by using a qualitative approach type of research procedures that can produce descriptive data in the form of documentation data, literature, written or oral words in the behavior of the people observed. Data sources consist of primary data and secondary data. Primary data is data obtained through observations of observations and direct interviews with Keuchik and Gampong Blok Sawah apparatus in Pidie Regency. While secondary data is data sourced from documents, books and reports relating to research and also related to the general state of the study area.

Informants in this study were determined by purposive sampling. Purposive sampling is a sampling technique in which the informant is taken intentionally by the researcher. By using purposive sampling research can be obtained in accordance with the object under study and expected characteristics of the sample in accordance with the required criteria. Data is collected through observation, interview and documentation techniques.

\section{Discussion}

Village administration is the process of managing and managing letters and other documents and relating to the administration of governance in the village. Orderly administration of Gampong is carried out by the apparatus who have been given the duties and responsibilities to carry out these tasks properly. But this is not an easy job because it requires adequate experience and knowledge so that the work will be effective and efficient. So that it requires the best work planning in order to be able to run in accordance with established regulations. The interview results show that Gampong apparatus of Blok Sawah has tried to realize the effectiveness of public services through several dimensions including simple, clear and certain services, open, efficient, economical and fair. This dimension is expected to contribute to the realization of the effectiveness of public services.

Based on the results of observations, researchers can conclude that by conducting coaching to the community through effective action it can lead to an achievement of 
success in the administration of Gampong administration. Efficient is the best comparison between input and output. as well as the optimal results in the ability to provide public services in terms of the administration of Gampong administration in the management of governmental governance carried out from Village Head and the staff in terms of licensing correspondence, according to the main tasks and functions of the Gampong government in terms of population.

Village administration is a very important scope of governance in the village, where administration, is a series of implementation in the government process in carrying out any service to the community and in development. The results showed that the population administration carried out by the Village government of the people who carried out the handling of certificates of birth, death, and moving out and into the population, which was carried out in the Village government from Village Head, Village Secretary, Head of Government Section and employees in the Government Field. In carrying out administration at the Keuchik Gampong Block Sawah office, it is carried out in the context of meeting the needs of the community and in implementing according to the provisions of the legislation.

Responsibility is the objective of the administration of the gampong government administration in carrying out every implementation in terms of service. Welfare sector. Based on the results of interviews and observations along with supported by existing documents, the researcher can conclude that the administration of Gampong administration in the Keuchik Gampong Blok Sawah office based on the policies that have been established, it can be said to be good.

The ability to carry out or carry out a job or task based on skills and knowledge and is supported by the work attitude required by the job. In terms of the discussion about the capabilities possessed by employees at Gampong office of Keuchik Gampong Blok Sawah in the administration of Gampong gampong administration. The results of the research show that in the field of ability, we do not guarantee that an employee has good abilities, in that field but that is in themselves. We only provide recommendations on the employee's educational background. But so far there are employees in certain positions in accordance with their educational capacity.

Likewise, a similar sentiment was also conveyed by other informants that: The administration of the gampong government administration in the process of handling the letter that we requested requires a long time to administer it. The same was conveyed by different informants that: Conducting Gampong administration requires the ability in terms of administration, as well as the ability to direct the community. Bearing in mind the need of the public for every administrative matter in government affairs.

Based on the results of interviews and observations the researcher can conclude that in terms of the ability and direction of the administration of Gampong administration, Gampong is still less alert and less responsive in responding to community complaints so that there are still gaps in service provided by Gampong apparatus. Then the educational factor is a factor that cannot be separated influence on employee performance, the higher the level of someone's education, the greater the level of understanding of tasks and functions, in other words, that one of the low educational factors can hinder the ability to carry out the tasks of the Gampong apparatus so causing ineffective implementation of the tasks of the Gampong Government and its apparatus, the ability and / or skill of each apparatus in the area of the task that becomes the task and responsibility is one of the determining factors for the effectiveness of the implementation of the tasks assigned to it.

The fact shows that this factor is lacking in every apparatus of Gampong Blok Sawah even though the level of formal education of each apparatus is considered to be sufficient, 
in which of the 7 officers consisting of Village Head, Village Secretary, five heads of Affairs, and 5 Heads the data / information presented in the register of existing registers and monographs is also related to the inability of the heads of the environment in submitting various reports or data needed by the secretariat for the need to register and make monographs in such circumstances.

An interview with the Keuchik Office Staff said that the secretary and head of affairs, including the head of the environment tend to lack commitment and dedication to carry out their duties properly, because it is caused by their low ability / skills, especially in terms of reporting and recording various activities or events that occur in the administration governance and development. The results showed that not all service employees could operate computers, only those employees who had special abilities were given the authority to operate these aids, so that when the authorized employee was not in place, work using tools was a little delayed ".

Indeed, the level of discipline that employees of the Gampong Blok Sawah is still low, sometimes employees come late and do not even come in for various reasons, this causes the ineffectiveness of existing services. However it is being pursued so that employees can comply. Based on the description of the interview results and observations mentioned above the researcher can conclude that the implementation of governmental tasks within and or Gampong employees tends to be increasingly ineffective, especially the implementation of administrative tasks in the narrow sense. The low education level also affects the mindset. So that it can be an obstacle in the implementation of the administration of Gampong administration at the Keuchik Gampong office in the Block Sawah, Pidie Regency.

Humans as one of the important resources in an organization are increasingly required to have expertise in their respective fields in order to carry out a task or job. This expertise greatly facilitates a person in completing each task given by the leader with expertise as well, the results of the work performed will be better, in addition to the human resource factor the implementation of the work can run properly the need for a good implementation system. In carrying out the administration of the gampong government in the Keuchik Gampong office in the Blok Sawah, Pidie Regency, in the case of moving letters, sometimes it takes a long time for the community to justify this.

Based on the results of interviews with one informant that community members must return to the Keuchik office over and over again, so that it takes time, especially if the distance we have to travel far enough not only when transportation costs are also the main thing. A similar sentiment was also conveyed by other informants that sometimes it is not the old management but because of overlapping work that slows the handling of the correspondence so that it becomes piling up.

Regarding the problem of service from employees in the Keuchik Gampong Blok Sawah office, there are still many shortcomings. Because now the activity of using a computer system is also a barrier when the computer has a problem, so the work becomes piling up and everyone demands to be resolved quickly. Based on the results of interviews and observations researchers can conclude that work on time is work that requires high concentration in order to achieve this it needs supporting things to facilitate the work. Both in terms of office equipment, knowledge to access computers, and a good environment for work. Furthermore, it relates to work facilities that can facilitate and launch a business. Something that can facilitate and launch a business is usually in the form of objects or money. The means referred to be the tools used to support and facilitate the performance of Keuchik Gampong Block Sawah office staff in serving the community. 
From the interview results above, the conclusion is that with the people of Gampong Block Sawah Pidie Regency, the facilities for work facilities are adequate, it should be able to make employee work faster, but in fact the employees have not been able to utilize the facilities to the fullest.

\section{Conclusion}

Based on the results of research conducted in the field, it can be concluded several conclusions as follows researchers conclude that administration is a collaboration carried out by a group of people and / or organizations based on the division of labor as determined in the structure by utilizing resources to achieve goals effectively and efficiently.

1. The implementation of Gampong Government administration in carrying out the management of the civil service administration of gampong government, Gampong Government is good enough and the Development of the Gampong Government's land issues is quite good with socialization to the community and mapping of the area, and has carried out population administration well done. The implementation of Gampong Government administration is certainly carried out in which Keuchik is assisted by gampong apparatus in the process of following the standards and mechanisms that involve professionals to update when there is a change in the government administration process in Gampong Blok Sawah Pidie Regency. The registration in the area of population is carried out every month, this is done to overcome the delay in population data collection because the data obtained is incomplete from the hamlet head or residents, so it does not make it difficult for Gampong officials to compile population data in accordance with the specified time.

2. The inhibiting factor in the administration of Gampong administration in Keuchik Gampong Blok Sawah Office Pidie Regency is due to the fact that Gampong officials have not been maximized to understand and understand good administration, limited knowledge facilities to support administrative activities, ineffective Gampong officials in carrying out their functions so that activities are often delayed. Low public awareness of the importance of self-identity, such as KTP, KK and other documents relating to national and state life.

\section{References}

Daryanto. (2015). Sosiologi Organisasi Suatu Pengantar. Jakarta: Raja Grafindo Persada.

Kaswan. (2012). Manajemen Sumber Daya Manusia untuk Keunggulan Bersaing Organisasi. Yogyakarta: PT. Raja grafindo Persada.

Manullang. (2014). Teori Organisasi. Jakarta: Universitas Terbuka.

Nurcholis, Hanif. (2011). Pertumbuhan dan Penyelenggaraan Pemerintahan Desa. Jakarta: Erlangga.

Qanun Provinsi Nanggroe Aceh Darussalam, Nomor 10 Tahun 2008 Tentang Pemerintahan Gampong.

Qanun Provinsi Nanggroe Aceh Darussalam, Nomor 5 Tahun 2003 Tentang Desa.

Silalahi, Ulbert dan Ibrahim Buddy. (2011). Study Administrasi. Bandung: Sinar Baru.

Thoha, Miftah. (2014). Birokrasi Pemeritahan Indonesi di Era Reformasi. Yogyakarta: Media Widya Mandala.

Wahyudi (2014). Beberapa Aspek Kebijakan Birokrasi. Yogyakarta: Media Widya Mandala. 